\title{
Capacity Building Institutional Department of Women's Empowerment, Child Protection, Population Control and Family Planning, Bintan Regency
}

\author{
Defitriyani Defitriyani ${ }^{1}$, Rumzi Samin ${ }^{2}$, Edy Akhyari ${ }^{3}$ \\ 1,2,3 Master of Public Administration Study Program, Faculty of Social Science and Political Science, \\ Universitas Maritim Raja Ali Haji, Tanjungpinang. Kepulauan Riau Province, Indonesia \\ ${ }^{1}$ Corresponding Author: defitriani85@gmail.com
}

Article Info

Article History; Received: 2021-10-08 Revised: 2021-12-22 Accepted: 2022-01-27

\begin{abstract}
Capacity Building as a form of institutional progress for the creation of better organizational performance in perfecting the implementation of the bureaucracy during the COVID-19 pandemic. The purpose of this study is to analyze capacity building in the Department of Women's Empowerment, Child Protection, Population Control and Family Planning, Bintan Regency. The research method used a qualitative approach by reviewing secondary data in the 2020 Government Agency Performance Accountability Report (LAKIP) and other documents which were then analyzed in-depth using the concept of institutional capacity building as a form of evaluating organizational performance in the future in reform bureaucracy. The results show that institutional capacity building in the Department of Women's Empowerment, Child Protection, Population Control, and Family Planning in Bintan Regency must support and inhibiting factors during the COVID-19 pandemic. it focuses on regulations and rules during a world health emergency that makes the government system not in a normal condition so that these inhibiting factors cannot be guaranteed to disappear. In addition, the supporting factor is organizational leadership ensuring that the vision and mission of the regional head as stated in the RPJMD in the Department of Women's Empowerment, Child Protection, Population Control and Family Planning in Bintan Regency, which gets special attention as stated in the mission of the Regent of Bintan Regency 2021-2026.
\end{abstract}

Keyword: Capacity Building; Institutional; Bintan Regency; COVID-19.

DOI: https://doi.org/10.18196/jgpp.v9i1.12892

\section{INTRODUCTION}

The government administration system is an element of important in a country. Therefore, the maintenance good governance is a demand for reform so that it becomes a mandate that must be implemented, especially by the apparatus as the administration of government (Hutchcroft, 2001). The effort to create good governance is reflected in the Decree of the MPR RI Number XI/MPR/1998 concerning the Implementation of a Clean and Free State of Corruption, Collusion and Nepotism. In Law Number 32 of 2004 concerning Regional Government, there is a decentralization of authority over all government affairs. However, prior to the enactment of the Law, it was known that the Regional Government was unable to manage its own household, where 
this right was obtained through the transfer of government affairs from the Central Government to the Regional Government (Andrews, 2010). The emergence of various government policies, especially the implementing policies of Law no. 32 of 2004 concerning Regional Government, in this case PP No. 6 of 2008 concerning Guidelines for Evaluation of the Implementation of Regional Government has become a key leverage for efforts to realize the capacity of regional governments.

Explained and mandated that the Government is obliged to follow up on the results of the implementation of performance evaluation local government by implementing capacity building programs (Akbar et al., 2015; Casey et al., 2012; Jurnali \& Siti-Nabiha, 2015). The mandate is clearly stated in the Guidance Chapter, Article 54 paragraph (1-3) PP No. 6 of 2008 concerning Guidelines for Evaluation of the Implementation of Regional Government as follows

1. The government based on the results of the evaluation of the regional government program conducts guidance and facilitation in the context of improving the performance of regional government through the program regional capacity development.

2. Capacity building can be in the form of facilitation in the areas of policy frameworks, institutions, and human resources.

3. The preparation of regional capacity development programs is guided by the national framework for capacity building as regulated by a Presidential Regulation.

Based on the substance of the article, capacity building for local government administration is in the form of coaching and facilitation in 3 (three) aspects, namely the policy framework, institutions, and human resources (Gargan, 1981; Gianakis \& McCue, 2019). In practice, there have been many capacity building programs carried out by various parties, including the Government, regional governments, and international donor agencies. The capacity of local government administration can be increased through capacity improvement at the level of policy making and implementing. Capacity building and development is a process carried out at three levels, namely individuals, groups and institutions or organizations, and aims to ensure the continuity of the organization through the achievement of the goals and objectives of the organization concerned (Merino \& Carmenado, 2012; Shiel et al., 2016).

Capacity building is a series of strategies aimed at increasing the efficiency, effectiveness, and responsiveness of government performance, by focusing on the dimensions: (1) development of apparatus resources; (2) organizational strengthening; and (3) institutional reform (Grindle, 1997). In addition, capacity building is a process that can increase the ability of a person, an organization, or a system to achieve the desired goals (Brown, 2001). However, capacity building is said to be a process to do something, or a series of movements, multilevel change within individuals, groups, organizations, and systems to strengthen the adaptability of individuals and organizations so that they can respond to changes in the existing environment (Morrison, 2001). Levels of Capacity Development, Capacity building must be carried out effectively and sustainably at three levels (Amadi, 2012; Ika \& Donnelly, 2017), namely, first, the system level, such as the framework related to regulations, policies and basic conditions that support the achievement of certain policy objectives, both institutional levels and the whole unit, The three levels are individual (Antlöv et al., 2010).

The understanding of Capacity building above can be said to be still limited to the human aspect only (human capacity), The development of human resource capabilities must be the priority by an organization, because excellent quality human resources will be able to encourage the formation of the ability of non-human factors optimally (Raynor et al., 2015). In other words, the ability of a region comprehensively is not only reflected in the capacity of its human resources, but also the capacity that is not in the form of human factors (non-human capacity), such as financial capacity and facilities to infrastructure or infrastructure(Laugesen, 2015; Nikitenko et al., 2017). Both HR capacity and non-HR capacity together will form the internal capacity of an organization (local government), However, even though the internal capacity of a local government is at a high level, it does not automatically say that the performance of the local government in aggregate is also high (Shipton et al., 2012). Here it is necessary to have external indicators that can be a factor for comparison or assessment and measurement of the internal capacity (Motra et al., 2016; Oudejans et al., 2011). 
As the previous research example explains that institutional capacity development Changes in the government system that directly or indirectly have a large enough influence on changes in development scenarios that have been formulated in activities that have been carried out in the local government planning process. Planning products prepared in the era before regional autonomy tended to a centralized approach. The planning process is in accordance with its hierarchy which does not yet fully have legitimacy as a binding regional development planning product if it has not been agreed upon, especially by the regional legislative council. Therefore, a review of the development planning process that has taken place so far is needed as part of efforts to improve institutional performance (Ambardi, 2007). The findings of other researchers also explain that the institutional arrangement carried out by local governments to realize Good Governance is still relevant to the implementation and distribution of authority in the structuring pattern. The application and procurement of technology facilities received the attention of respondents that they were still feasible and capable of being a supporter in operations. Meanwhile, in terms of personnel placement, it can be used as a reference that personnel are able to synergize with their duties and responsibilities, as well as in cooperating as an organizational unit (Thaha, 2009). in addition to strengthening institutional capacity and executing institutional capacity building initiatives undertaken by the Organization and Management Section, as well as factors obstructing and facilitating institutional capacity building efforts. The study findings are anticipated to provide guidance to the Blitar City Government, particularly the Organization and Management Section, in its efforts to strengthen institutional capacity (Ningtyas, 2014).

This is based on the idea that high internal capacity is a prerequisite for creating high external performance indicators, it is unreasonable that external performance can be driven by limited internal capabilities (Sinthupundaja et al., 2018; Zouaghi et al., 2018). Capacity building tends to be identified with organizational and institutional skills and resources. For example, it has been indicated as a means of ensuring the continued existence of the organization by building institutional strength and reducing dependence on key individuals. Effective capacity building enables the organization to continue its work despite staff changes or changes in the operating environment (Fanany et al., 2010; Hudalah et al., 2010). In general, the purpose of capacity building is of course so that individuals, organizations, and existing systems can be used effectively and efficiently to achieve the goals of these individuals and organizations. The main task of the Department of Women's Empowerment, Child Protection, Population Control and Family Planning in Bintan Regency is to provide support to regional heads in formulating and implementing regional policies in the fields of Women's Empowerment, Child Protection, Population Control and Family Planning.

So, this study aims to evaluate capacity building in analyzing the Government Agency Performance Accountability Report (LAKIP) in 2020 by the Department of Women's Empowerment, Child Protection, Population Control and Family Planning in Bintan Regency during the COVID-19 pandemic. Performance is the result of work achieved by employees in develop tasks and work that comes from the organization. Performance is also a result of work produced by individuals through the processes of the organization or company that can be measured concretely and compared through standards that have been determined by the company or organization (Borman \& Motowidlo, 1997; Sonnentag \& Frese, 2005).

Performance organization that has been achieved in completing assigned tasks and responsibilities within a certain period. Performance is a function of motivation and ability. To complete a task or job, one should have a certain degree of willingness and level of ability (Bonner \& Sprinkle, 2002; Borman \& Motowidlo, 1993). In the performance of government agencies and useful for encourage government agencies to carry out general government tasks and build good and true (Good Governance) based on applicable laws and regulations, transparent, measurable and accountable policies to the community, make government agencies accountable so that they can operate effectively, efficient and responsive to the aspirations of the community and the environment, providing input and feedback for interested parties in order to improve the performance of government agencies, as well as maintaining public trust in the government (Gianakis \& McCue, 2019). 


\section{RESEARCH METHOD}

The type of research used is in the form of descriptive research, where the research studies secondary data (Johnston, 2014). Secondary data is data that has been processed first and only obtained by researchers from other sources as additional information. The main secondary data that has been obtained include the Report of Government Agency Performance Accountability Report (LAKIP) in 2020 by the Department of Women's Empowerment, Child Protection, Population Control and Family Planning in Bintan Regency. In addition, the researchers collected several supporting data such as e-journals, websites, documentation, government publications and other supporting sites or sources (Galvan \& Galvan, 2017; Moleong, 2012). Then the data analysis carried out consists of three flows that occur simultaneously, namely: data reduction is defined as the selection process, focusing attention on simplification, abstraction, and data transformation. Furthermore, triangulation as a technique to check the validity of the data by comparing some of the data obtained and finally drawing conclusions (Miles et al., 2014).

\section{RESULT AND DICUSSION}

\section{Institutional Capacity Building in Department of Women's Empowerment, Child Protection, Population Control and Family Planning, Bintan Regency}

\section{Organizational structure}

The theory of organizational dimensions in capacity building according to (Kaplan, 2010) that one of organizational strengthening focuses on organizational processes and structures that can influence how the organization sets its goals and organizes its work intensively so in the institution there is a need for an adequate organizational structure. The Bintan Regency Department of Women's Empowerment, Child Protection, Population Control, and Family Planning was established based on the Bintan Regency Regional Regulation Number 7 of 2016 concerning the Establishment and Structure of the Bintan Regency Regional Apparatus. Bintan Regent Regulation Number 31 of 2016 stipulates the Organizational Structure of the Regional Apparatus for the Department of Women's Empowerment, Child Protection, Population Control, and Family Planning in the Bintan Regency. The Main Duties and Functions of the Department of Women's Empowerment, Child Protection, Population Control, and Family Planning in Bintan Regency in the main task of providing support to the Regent of Bintan in formulating and implementing regional head policies.

While the functions of formulating technical policies, fostering the implementation of tasks, implementing administrative affairs of the service, and carrying out tasks assigned by regional heads. Then in the organizational structure, there will be synergies between lines and functions so that goals can be achieved. In running the organization, the Department of Women's Empowerment, Child Protection, Population Control, and Family Planning in Bintan Regency is supported by 26 civil servants (PNS) and 11 honorary employees. Based on this explanation, the arrangement of the organizational structure of the Regional Government with the right function and size is also carried out through departmentalization and specialization which emphasizes emphasizing the important elements in designing the organizational structure. this is evidenced in the structural design that underlies the division of tasks according to each field that has been described in the main tasks and functions in the Department of Women's Empowerment, Child Protection, Population Control and Family Planning, Bintan Regency.

\section{Work Mechanism}

An organization has a working mechanism that can realize good governance in accordance with the shared aspiration in completing tasks to achieve common goals, this strengthens the characteristics of capacity building in the form of a continuous improvement process which means it is an internal process that can only be functioned and accelerated with the assistance of outside, through a working mechanism with various parties involved in the development of institutional capacity (Kinsey \& Raker, 2003). The working mechanism in question is the Determination of Performance at the Department of Women's Empowerment, Child Protection, 
Population Control, and Family Planning Bintan Regency consist of 2 strategic targets in accordance with the SKPD and RPJMD strategic plans (2021-2026).

Namely the first to control population growth and increase quality and prosperous families. secondly, increasing gender equality and justice in development and the protection of women and children. To achieve the strategic and indicator targets, several important programs and activities related to these targets with a budget of IDR 10,065,280,993, - Based on this explanation, the improvement of work mechanisms and methods as well as inter-sectoral work relations in the Department of Women's Empowerment, Child Protection, Population Control and Family Planning in Bintan Regency requires innovation and strategies in providing productive programs during the COVID-19 pandemic. so that it can maximize all existing potential in accordance with the Vision and Mission of the Organization to provide an overview of the level of achievement of performance targets and programs/activities as determined.

\section{Organizational Culture}

One of the dimensions of capacity building within the organization is organizational strengthening, one of which is strategy and culture (Edgar, 1937). The relationship between the two shows the need for direction on one aspect, namely the process of achieving effective goals by developing an organizational culture system with leadership, communication, and value systems strategies. From the results of data analysis obtained on Women's Empowerment, Child Protection, Population Control, and Family Planning in Bintan Regency, there is an organizational culture built to provide a positive effect in the implementation of all work activities to achieve common goals. Judging from PP No. 59 of 2012 concerning the National Framework for Regional Capacity Development in terms of organizational culture, it is clearly stated that institutional capacity development has indicators in institutionalizing a productive and positive organizational culture based on the noble values of the nation's culture.

According to the results of research on The Department of Women's Empowerment, Child Protection, Population Control, and Family Planning in Bintan Regency has implemented a value system that forms the basis for work ethics. It can be in the form of politeness, hospitality, communication that shows a noble value of the nation. Thus, from this participatory and democratic process, there is growing work motivation. By being strengthened on the value of employee discipline, the development of institutional capacity in the Department of Women's Empowerment, Child Protection, Population Control and Family Planning in Bintan Regency is increasingly maximized, this is reinforced by the enactment of PP no. 53 of 2010 concerning Civil Servant Discipline, the supervision is stricter, and the punishment is firmer and heavier.

\section{The Budget/Value System}

Task autonomy is influenced by several factors wrong the only thing is that the finances must be sufficient and good in implementing the program (Kaho, 2005). In the institutional capacity building program at the Department of Women's Empowerment, Child Protection, Population Control, and Family Planning, Bintan Regency, a budget allocation is needed to support the implementation of all organizational activities. In accordance with the World Bank theory which emphasizes capacity building attention to the focus of the organizational environment that leads to financial and budgetary support in realizing all activities and organizational needs. According to the researcher, the budget allocation that has been described previously provided from the pure regional budget of Bintan Regency is adequate, although seen from 2021-2026 it has decreased due to the COVID-19 pandemic. This is in accordance with PP No.59 of 2012 concerning the National Framework for Regional Government Capacity Development Article 20 paragraph 2 that regional government capacity development programs and activities carried out by regional governments are charged to their respective Regional Revenue and Expenditure Budgets.

Facilities and infrastructure

One of the factors that influence regional autonomy is good enough equipment needed for the creation of good local government such as office equipment, tools communication, Page | 66 
transportation (Kaho, 2005). The development of infrastructure facilities is implemented periodically by the Department of Women's Empowerment, Child Protection, Population Control, and Family Planning in Bintan Regency because it remembers the importance of adequate infrastructure to help facilitate the work of employees. This is in accordance with PP No. 59 of 2012 concerning the National Framework for Regional Government Capacity Development Article 6 paragraph 2 that institutional capacity development includes one of which is the provision of infrastructure facilities that are in accordance with established standards, infrastructure facilities that meet standards are adequate and can still function properly according to the needs of the organization. Based on the explanation above that Department of Women's Empowerment, Child Protection, Population Control, and Family Planning in Bintan Regency the management of facilities and infrastructure must always pay attention to the laws, regulations, instructions, and technical instructions imposed by the authorities. It is intended that the procurement of facilities and infrastructure must be carried out through careful planning so that they are used carefully to reduce waste during the COVID-19 pandemic.

Factors in Institutional Capacity Building in Department of Women's Empowerment, Child Protection, Population Control and Family Planning, Bintan Regency

Supporting Factors

a. Leadership: Organizational leadership, some of which are providing mutual support, acknowledging the achievements of team members, encouraging, and making it easier for members to work, trying to maintain commitment (Yukl, 2010). The leadership in the Department of Women's Empowerment, Child Protection, Population Control, and Family Planning in Bintan Regency applies this in its role to successfully achieve common goals. Leaders are wise in making decisions through deliberation with employees in terms of evaluating work and planning work according to the ideas submitted by members. This is also evidenced by the mission of the Regent of Bintan Regency point six, namely Optimizing community empowerment, Realizing Social Welfare, and gender mainstreaming in various aspects of development.

b. Shared Commitment: Capacity building takes a long time and requires a long-term joint commitment and all parties involved in the stakeholder actors (Dessler, 1992). In accordance with what is available in the Department of Women's Empowerment, Child Protection, Population Control, and Family Planning, Bintan Regency, a shared commitment is maintained and developed in a harmonious and conducive working relationship through mutual respect, mutual respect, and trust among employees, not only for staff only but both superiors to subordinates and subordinates to their superiors in terms of carrying out the tasks carried out in accordance with the main objectives and functions of the Department of Women's Empowerment, Child Protection, Population Control and Family Planning in Bintan Regency, namely strengthening the Regional Technical Implementation Unit (UPTD) of the Department of Women's Empowerment, Child Protection, Population Control and Family Planning in Bintan Regency and is operationally coordinated by the sub-district head in his working area of Bintan Regency.

Obstacle Factor

a. Inconsistency of Regulations; The existence of regulations that often change during the COVID-19 pandemic, both technical regulations and substance regulations regulated by the central government and local governments in carrying out the program of the Department of Women's Empowerment, Child Protection, Population Control and Family Planning in Bintan Regency, the employees find it difficult to completion of main tasks and functions in implementing health protocols to prevent the spread of the COVID-19 pandemic. Not only in these conditions, but there are also too many regulations regarding employment laws in this pandemic disaster situation, so it is impossible for employees to implement these rules in a health emergency that afflicts the whole world. One of the 
factors affecting capacity building is that regulatory reform cannot be implemented practically

b. COVID-19 pandemic conditions; In conditions of the COVID-19 pandemic, it is difficult to develop capacity on a regular basis, this is because there is a priority program from the central government in the form of synchronizing recovery to increase insight into the importance of health protocols in deciding the spread of the COVID-19 pandemic in the Department of Women's Empowerment, Child Protection, Population and Family Control Planning for Bintan Regency. then the inhibiting factor will be efficiency which must be reduced when there is a change in the annual work program.

\section{CONCLUSION}

Institutional capacity building in case studies in organizational structure, organizational culture, supporting facilities, work mechanisms and budgeting values is quite disrupted or there are slight gaps carried out during the COVID-19 pandemic, program priorities according to the vision and mission of the regional head in Bintan Regency, so that there is a pattern changed performance and slightly changed standard operating procedures. then in the execution of institutional capacity building emphasis on prioritized initiatives. While the supportive variables include leadership and common commitment, while the challenges are regulatory discrepancies during the COVID-19 pandemic and the COVID-19 pandemic circumstances in a public health emergency. the existence of inhibiting factors in the development of institutional capacity, suggestions can be taken, among others, regarding the inconsistency of rules to pay more attention to clarification and anticipation in the implementation of the wheels of government during the COVID19 pandemic at the Office of Women's Empowerment, Child Protection, Population Control and Family Planning in Bintan Regency.

\section{REFERENCE}

Akbar, R., Pilcher, R. A., \& Perrin, B. (2015). Implementing performance measurement systems: Indonesian local government under pressure. Qualitative Research in Accounting \& Management, 12(1), 3-33. https://doi.org/10.1108/QRAM-03-2013-0013

Amadi, B. O. (2012). Perceptions of Capacity Building among Youths Involved in Vocational Skills Development. Journal of Social and Development Sciences, 3(6), 214-222. https://doi.org/10.22610/JSDS.V3I6.705

Andrews, M. (2010). Good Government Means Different Things in Different Countries. Governance, 23(1), 7-35. https://doi.org/10.1111/J.1468-0491.2009.01465.X

Antlöv, H., Brinkerhoff, D. W., \& Rapp, E. (2010). Civil Society Capacity Building for Democratic Reform: Experience and Lessons from Indonesia. VOLUNTAS: International Journal of Voluntary and Nonprofit Organizations, 21(3), 417-439. https://doi.org/10.1007/S11266010-9140-X

Ambardi, U. M. (2007). Analisis Kinerja Kelembagaan Pembangunan Pulau Natuna. Jurnal Sains dan Teknologi Indonesia, 9(3). https://doi.org/10.29122/jsti.v9i3.783

Bonner, S. E., \& Sprinkle, G. B. (2002). The effects of monetary incentives on effort and task performance: theories, evidence, and a framework for research. Accounting, Organization and Society, 27(1), 303-345. www.elsevier.com/locate/aos

Borman, W. C., \& Motowidlo, S. J. (1997). Task performance and contextual performance: The meaning for personnel selection research. Human Performance, 10(2), 99-109.

Borman, W. C., \& Motowidlo, S. M. (1993). Expanding the criterion domain to include elements of contextual performance. Personnel Selection in Organizations, December. 
Brown, L. (2001). Measuring capacity building. Carolina Population Center. https://doi.org/10.4324/9781003235361-36

Casey, M. M., Payne, W. R., \& Eime, R. M. (2012). Organisational readiness and capacity building strategies of sporting organisations to promote health. Sport Management Review, 15(1), 109-124. https://doi.org/10.1016/J.SMR.2011.01.001

Dessler, G. (1992). How to earn your employees' commitment. The Academy of Management Executive, 13(2), 58-67.

Edgar, S. (1937). Organizational Culture and Leadership Defined. In Zhurnal Eksperimental'noi i Teoreticheskoi Fiziki (pp. 21-320). Wiley.

Fanany, I., Fanany, R., \& Kenny, S. (2010). Capacity Building in Indonesia: Building What Capacity? In Challenging Capacity Building. Palgrave Macmillan, London. https://doi.org/10.1057/9780230298057_8

Galvan, J. L., \& Galvan, M. C. (2017). Writing literatur reviews: A guide for student of the social and behavior sciences (7th ed.). Routledge.

Gargan, J. J. (1981). Consideration of Local Government Capacity. Public Administration Review, 41(6), 649. https://doi.org/10.2307/975741

Gianakis, G. A., \& McCue, C. P. (2019). Local Government Capacity Building Through Performance Measurement. In Handbook of Local Government Administration (pp. 239-261). Routledge. https://doi.org/10.4324/9781315093239-11

Grindle, M. S. (1997). Getting good government: capacity building in the public sectors of developing countries. Harvard Institute for International Development, Harvard University.

Hudalah, D., Winarso, H., \& Woltjer, J. (2010). Policy networking as capacity building: An analysis of regional road development conflict in Indonesia: Planning Theory, 9(4), 315-332. https://doi.org/10.1177/1473095210368776

Hutchcroft, P. D. (2001). Centralization and Decentralization in Administration and Politics: Assessing Territorial Dimensions of Authority and Power. Governance, 14(1), 23-53. https://doi.org/10.1111/0952-1895.00150

Ika, L. A., \& Donnelly, J. (2017). Success conditions for international development capacity building projects. International Journal of Project Management, 35(1), 44-63. https://doi.org/10.1016/J.IJPROMAN.2016.10.005

Johnston, M. P. (2014). Secondary Data Analysis: A Method of which the Time Has Come. Qualitative and Quantitative Methods in Libraries, 3(3), 619-626. http://www.qqmljournal.net/index.php/qqml/article/view/169

Jurnali, T., \& Siti-Nabiha, A. K. (2015). Performance Management System for Local Government: The Indonesian Experience: Global Business Review, 16(3), 351-363. https://doi.org/10.1177/0972150915569923

Kaho, J. R. (2005). Prospek Otonomi Daerah di Negara Republik Indonesia. Rajawali Pers.

Kaplan, A. (2010). Capacity building: Shifting the paradigms of practice. Development in Practice, 10(3-4), 517-526. https://doi.org/10.1080/09614520050116677

Kinsey, D. J., \& Raker, J. R. (2003). Capacity building: A primer. New Directions for Philanthropic Fundraising, 2003(40), 5-14. https://doi.org/10.1002/PF.29

Laugesen, M. J. (2015). Human Resources in Health Care Systems: Reflecting on 'Cross-National Comparisons of Human Resources for Health - what can we learn?' Health Economics, Policy and Law, 10(4), 375-379. https://doi.org/10.1017/S1744133115000080 
Merino, S. S., \& Carmenado, I. de los R. (2012). Capacity Building in Development Projects. Procedia - Social and Behavioral Sciences, 46, 960-967. https://doi.org/10.1016/J.SBSPR0.2012.05.231

Miles, M., Huberman, M., \& Saldana, J. (2014). Qualitative data analysis. SAGE Publications.

Moleong, L. J. (2012). Metodelogi penelitian kualitatif. Remaja Rosdakarya.

Morrison, T. (2001). Actionable learning: a handbook for capacity building through case-based learning. Asian Development Bank Institute.

Motra, H. B., Stutz, H., \& Wuttke, F. (2016). Quality assessment of soil bearing capacity factor models of shallow foundations. Soils and Foundations, 56(2), 265-276. https://doi.org/10.1016/J.SANDF.2016.02.009

Nikitenko, G. V., Zvyagintseva, O. S., Sergienko, E. G., Babkina, O. N., \& Chernikova, L. I. (2017). Development of Human Resources of the Organization with the Help of Team-Building Model. Calitatea, 18(157), 132-133.

Ningtyas, M. (2014). Upaya Pemerintah Daerah dalam Meningkatkan Kapasitas Kelembagaan (Studi pada Bagian Organisasi dan Tata Laksana Pemerintah Kota Blitar). Jurnal Administrasi Publik, 2(4), 687-693.

Oudejans, S. C. C., Schippers, G. M., Schramade, M. H., Koeter, M. W. J., \& Brink, W. van den. (2011). Measuring the learning capacity of organisations: development and factor analysis of the Questionnaire for Learning Organizations. BMJ Quality \& Safety, 20(4), 307-313. https://doi.org/10.1136/BMJQS.2010.042556

Raynor, J., Cardona, C., Knowlton, T., Mittenthal, R., \& Simpson, J. (2015). Capacity Building 3.0: How to Strengthen the Social Ecosystem. In Briefing Paper.

Shiel, C., Leal Filho, W., do Paço, A., \& Brandli, L. (2016). Evaluating the engagement of universities in capacity building for sustainable development in local communities. Evaluation and Program Planning, 54, 123-134. https://doi.org/10.1016/J.EVALPROGPLAN.2015.07.006

Shipton, H., Budhwar, P. S., \& Crawshaw, J. (2012). HRM, Organizational Capacity for Change, and Performance: A Global Perspective. Thunderbird International Business Review, 54(6), 777790. https://doi.org/10.1002/TIE.21503

Sinthupundaja, J., Chiadamrong, N., \& Kohda, Y. (2018). Internal capabilities, external cooperation and proactive CSR on financial performance. The Service Industries Journal, 39(15-16), 1099-1122. https://doi.org/10.1080/02642069.2018.1508459

Sonnentag, S., \& Frese, M. (2005). Performance Concepts and Performance Theory. Psychological Management of Individual Performance, October 2017, 1-25. https://doi.org/10.1002/0470013419.ch1

Thaha, R. (2009). Penataan Kelembagaan Pemerintahan Daerah. GOVERNMENT: Jurnal Ilmu Pemerintahan, 39-62.

Yukl, G. A. (2010). Leadership in organizations. Upper Saddle River, Prentice Hall.

Zouaghi, F., Sánchez, M., \& Martínez, M. G. (2018). Did the global financial crisis impact firms' innovation performance? The role of internal and external knowledge capabilities in high-, and low-tech industries. Technological Forecasting and Social Change, 132, 92-104. 